2020, Volume 14, International Conference Innovative Business Management \& Global Entrepreneurship (IBMAGE 2020), pages: 734-743 | https://doi.org/10.18662/lumproc/ibmage2020/54

\section{Ecotourism in Bucovina}

\section{Otilia CRĂCIUN (RADU) ${ }^{1}$, Cristina Gabriela VASCIUC (SĂNDULESCU) ${ }^{2}$, Dumitru SĂNDULESCU ${ }^{3}$}

${ }^{1} \mathrm{PhD}$, Faculty of Economic Sciences "Valahia", University of Târgovişte, România, otiliaradu@yahoo.com ${ }^{2} \mathrm{PhD}$, Faculty of Economic Sciences "Valahia", University of Târgovişte, România, crisabebe2005@yahoo.com ${ }^{3} \mathrm{PhD}$, Faculty of Economic Sciences "Valahia", University of Târgoviște, România, miti.sandulescu@yahoo.com
Abstract: Bucovina, a part of northern Romania, is the image of painted monasteries, both inside and outside, recognized worldwide: Voroneț Monastery, Humor Monastery, Sucevița Monastery, Moldoviţa Monastery, Arbore Monastery. These architectural wonders are surrounded by natural riches, a diverse ecosystem with lakes, mountains and valleys, and gentle and hospitable people entice you with specific foods and crafts from craftsmen (potters, egg decorators, etc.).

Bucovina meets the conditions for the development of ecotourism and in this article we will demonstrate that this branch of the hospitality industry can differentiate between past and future, and ecotourism is the best method of capitalizing on nature, traditions, culture and economic growth.

Keywords: ecotourism; tourism; management; strategies.

How to cite: Crăciun (Radu), O., Vasciuc (Săndulescu), C.G., \& Săndulescu, D. (2020). Ecotourism in Bucovina. In M. W. Staniewski, V. Vasile, \& A. Grigorescu (vol. ed.), Lumen Proceedings: Vol. 14. International Conference Innovative Business Management \& Global Entrepreneurship (IBMAGE 2020) (pp. 734-743). Iasi, Romania: LUMEN Publishing House. https://doi.org/10.18662/lumproc/ibmage2020/54 


\section{Introduction}

When we have to talk about something dear to us, it is very difficult, because your mind is flying not to Romania now, but to old Dacia, to "Mountain Dacia" described so beautifully by Dimitrie Cantemir [2], who makes a review of the natural patrimony, when it tells of waters, mountains, plains and fairs or of the flora and fauna that over time have remained the same; of customs, which live even today - customs of engagement, wedding and burial, etc .; of the monasteries built by the rulers or the boyars of those times, as a thank you for the victories acquired, on the battlefield or at negotiations; of the Romanian (Moldovan) language, very similar to that of the Italians. I searched for the word Bucovina and it was described as "Red groves, meaning forests of red oaks, because they were watered with faint blood; the corpses call it Bucovina and I never mention this place without shedding tears" [2]. History is always part of the past of a people and if over time there have been more rulers in the area, nature has remained just as wonderful, and people with all the hardships they have had to face, have remained welcoming Romanians, people of all do and anchor strongly in Orthodoxy.

Bucovina means nature, unique monasteries in the world, cultural and historical richness, traditions and craftsmen, good accommodation and rich meals, often based on products from the households of peasants in the area and therefore is a national and international tourist destination.

When we say nature we think of mountains, hills and plateaus, Vanatori Neamt National Park, Ceahlau National Park, Falticeni Lakes located in the Suceava Plateau or in the Suceava Depression are protected areas, Natura 2000 sites, surrounded by agricultural land, pastures, orchards there are stops for 20,000 migratory birds, the reed heron (Circus aeroginosus), the pond ox (Botaurus stellaris), the dwarf heron (Ixobrichus minutus), etc. being a good place to watch birds [7].

When we say monasteries we bring first of all the painted monasteries both inside and outside Arbore Monastery, Sucevita Monastery, Humor Monastery, Moldovita Monastery and last but not least Voronet Monastery, with the blue of Voronet, but we do not forget other monasteries that are oases of peace and beauty such as Putna Monastery, Agapia Monastery, Varatec Monastery and many others.

Apart from monasteries and nature, there are many other tourist attractions such as Neamt Fortress, Suceava Fortress, Ion Creanga Memorial House, Ciprian Porumbescu Memorial House, museums, theaters, festivals that enrich the tourist heritage of the area. 
Traditions have their place in national parks where crafts and local craftsmen are promoted in the events they organize and in visitor centers, offer the possibility for local community craftsmen to exhibit their products such as the Visitor Center of Vânători Neamț Natural Park, where there is a Community Center for locals, which organizes: meetings for learning the traditional crafts of the area, training the population of the area in actions aimed at nature conservation, permanent and temporary exhibitions [3].

A traveler in Bucovina can enjoy all these possibilities of spending his free time walking and following the evolution of natural beauties, learning a little iconography or history, having various accommodation and restoration services, from pensions, to hotels and enjoying a Moldovan meal with local drinks and can talk about ecotourism as a form of sustainable development of this region.

\section{Problem Statement}

Bucovina is one of the most sought after areas in Romania, from a tourist point of view because it has a wide market of tourist and natural and anthropic attractions. This is the reason why there are so many articles written about this destination. Of all the tourist destinations in Romania, Bucovina stands out through a competitive niche tourism, so that in 2010 it was among the preferences of British tourists [8] by combining the tourist offer with the experiences gained.

In Bucovina, the industry is represented too little, there are some garment companies, forestry, etc., which led to increased unemployment in the area, and the population was forced to reorient, to re-profile to tourism [6].

At the same time, the existence of a UNESCO patrimony of incomparable value has put on the international and national map of tourism, this destination, Bucovina, thus adding value to this patrimony, by offering jobs, jobs that involve traditions and culture in rural communities [11], presenting a simple way of life, harmonized with nature.

The hospitality industry has had the highest economic growth in recent years, and its newest branch is ecotourism, or as they say responsible tourism.

The latest definition of ecotourism was given in 2015 by the International Ecotourism Association which states: "responsible travel to natural areas that conserves the environment, sustains the well-being of local people, and involves interpretation and education" [10] and which also outlined the principles of this form of tourism. 
In Romania, the Romanian Ecotourism Association (AER) defines the following elements as determined for ecotourism:

- Leads to biodiversity conservation;

- Emphasizes the initiative of the local community;

- Small business development;

- Use of local labor force;

- It brings economic and spiritual added value to the local population in the vicinity of natural areas;

- Educates both locals and tourists to protect the environment, to enjoy a clean life;

- The negative impact on natural, cultural and social environment to be minimal [1].

In this article based on fundamental research and research based on the field observation method, can demonstrate that Bucovina is an ecotourism destination, having met all those requirements, principles of ecotourism and can develop improvement strategies for the development of this region

\section{Aim of the research.}

The purpose of the research conducted in Bucovina is to prove through observations made on the spot in July and August, in 2018, 2019 and 2020 that ecotourism is present in Bucovina and that every condition is met, to put Bucovina on the map of international ecotourism. And because we want it to be recognized internationally as an ecotourism destination, we further base our research on studying the principles issued by The International Ecotourism Society, which states them as follows [10]:

1. Minimal negative impact.

2. Respect and awareness for nature and culture.

3. Positive experiences for tourists and hosts

4. Part of the profit of ecotourism to return to the community for conservation.

5. Generating added value locally

6. Memorable experiences for tourists to make them aware of the specific climate of the country

7. Construction of pensions, roads with low impact on the environment

8. Respecting the rights of locals and collaboration between them and between NGOs, private companies and public administration

and on the Ecotourism Development Strategy in Romania 20152020 [2] and on the National Ecotourism Strategy 2019-2029 [9]. 
We intend to give only a few examples, among the many that prove that it exists ecotourism in this part of Romania and we will not talk about the Campulung Moldovenesc - Vatra Dornei area, which has been very well treated so far in various studies [6, 4]. In the introduction we marked the areas of interest for this article, because the region is vast and above it we can write whole treatises.

\section{Research Methods}

The first research method used was the fundamental research method in which documents were studied, articles about the Bucovina region, from Romania and about ecotourism, recent documents, the oldest being written in 2010, from the online environment, the only exception being a Romanian book "Description of Moldova" by Dimitrie Cantemir, which is actually natural and anthropic history, because it reproduces very well both aspects of Moldova and implicitly of Bukovina. This type of research, fundamental research creates a starting point in any research and gives you ideas about where you want to go. If we review ecotourism, the evolution of this form of tourism we notice that it was first discussed in the 1990s, but the real development takes place after 2002, and the fact that NGOs have been set up locally and internationally, which created the theoretical and practical bases of ecotourism, leads to the correct realization of this type of tourism.

The second research method is the method of direct observation of the tourist phenome in Bucovina, in two important months of the year, July and August, when the tourist flow increases due to summer holidays, holidays that are longer and allow you to travel on longer distances. In three consecutive years 2018, 2019 and 2020, in the two months we noticed the behaviour of many tourists, who visited Bucovina, we studied the points of interest for them and we can say that those up to 30-35 years old made trips in the protected areas, in nature and regardless of age, the monasteries and fortresses of Bucovina had the highest degree of visitation, followed by the Ion Creanga Memorial House. During the week the number of tourists was small, most of them arrived in the area with their own means of transport, on weekends there were more tourists arriving at destinations with coaches and minibuses transporting classified persons, who had or did not have an authorized guide. Tourists who are accompanied by an authorized guide or a ranger receive information on the way and once they reach the objectives have beautiful experiences, which remain as beautiful memories, because someone explained to them where they are, what happened or who painted 
the monastery church and then tourists start to process, thinking about the times when they went alone and looked, marvelled and that's it.

\section{Findings and Discussions}

Using the research method of observation in July, August for the years 2018, 2019 we could count on the days of the week from Monday to Friday on average 2, 3 coaches / day with 45-50 people and 2, 3 minibuses / day with 16-19 people, and on Saturday and Sunday 8, 10 coaches / day with 45-50 people and 5, 6 minibuses / day with 16, 19 people, who parked at a tourist attraction between an hour and two hours, which leads us to an average of 7000 tourists / month come in organized group. In July and August 2020 during the week very rarely a bus / week with 35-45 passengers, the number of minibuses at most 1 / week during the week 1619 tourists and on Saturdays and Sundays 2 buses with 35-45 and 4 minibuses with 16-19 passengers, which leads to a number of approximately 1000 tourists / month, who visit the same tourist attractions in an hour or two, depending on how many tourist attractions are included in the program. The fact that in 2020 there are fewer tourists leads to more pleasant experiences, but to the decrease of the economic added value in the area.

Having this starting point, we study the principles of ecotourism in the Bucovina area and we will start not as they are numbered but in the order in which they must be taken into account. In our opinion, the first principle is to educate hosts and tourists for awareness and respect for the natural environment and culture, and this principle is reflected in the Vanatori-Neamt National Park through education programs for locals and tourists who reach those events, of which we can mentioned - "The road of a forest" - "Ana has apples ... for bison, and the fact that the park administration has a textbook" Bison Land ", and this optional subject taught in schools in the area of protected natural area, and periodically organizes actions greening - sanitation of certain areas with the help of volunteers. Here, as a strategy for the future, we can add a greater popularization of events, not only locally, but in the country through travel agencies and travel sites.

Starting from education we reach positive experiences for tourists and hosts and knowing the climate of our country in that region. When we talk about experiences, it is good in our opinion to put them together because you do not create experiences only for iconography, if you visit a monastery, but we create experiences in terms of the whole as such. Take for example the Sucevita Monastery, a monastery of nuns, with interior and 
exterior painting in which the color green predominates, but in a white rectangle, divided into several frames we have the story of Adam and Eve, which we may not have noticed- $\mathrm{o}$ if the guide nun hadn't told us about her, about heaven and about the earth. I saw many groups sipping the words of the guide, and when the explanations ended, the tourists looked once more so as not to forget and then went to admire the surroundings, the courtyard of the monastery, the surrounding areas, very beautiful areas. In the case of pilgrimages, tourists did not forget to light a candle and pray for themselves, their families and the whole world. The monastery museum reveals the art of painting, fabrics and holy books and these lead to other experiences, and at the store you can find in addition to books and products made by nuns and honey, jams, jams, teas and even a whole natural family. From the sale of these products is obtained an added value, which returns to the monastery for the maintenance of the monument, especially as it is one of the monasteries in the UNESCO patrimony, and which received together with four other painted monasteries, the recognition "Golden Apple", as being unique in the world and of an incomparable beauty.

Tourists stay with experience and when they get home, when they taste the honey or jam bought from Sucevita Monastery, they gain other experiences, sensory experiences, which bring to mind the images seen. And easily starting from the principles of ecotourism that it offers special experiences, we reach economic surplus value, which returns to the community to maintain natural or anthropic values and we come to bring to the fore the principle of generating added value locally and the principle of returning a parts of the profit to the conservation of the patrimony. Another example is the Black Shirt Workshop from Marginea, a small family business, but when you see the potter making living clay and from a lump of mud a vase is born, you surely go with him and buy at least a cup of black pottery or red pottery. And again you take home with beautiful experiences, traditions, which you continue at Customs, at the Egg Museum, where you look from biblical eggs, to ostrich eggs decorated or worked in wax, beads or semiprecious stones and we reach other pleasant experiences. for tourists and if they do not leave empty-handed, but buy an egg, two, material value is produced, which can be returned to the tradition of decorating eggs.

Along the way you meet beautiful houses and small guesthouses with 10-15 places of accommodation or larger with over 50 places, all of which are drawn from story books, and the beautifully paved roads are available to tourists making it easier to access natural areas. protected, fortresses, monasteries, memorial houses and other tourist attractions. And from this point of view, Bucovina is doing quite well. However, if the number of tourists increases, the accommodation capacity will be small, in relation to 
the needs, and the roads will be quite insufficient for a higher traffic. Here the public administration must work with private entrepreneurs and make a plan for widening, where possible, the roads, because it is important to be able to get where you want, where you intend to visit. As a strategy to receive as many visitors as possible, it is to increase the number of pensions, hotels, renovate and modernize old hotels and widen the roads.

In the context of ecotourism development, an important role is played by associations that deal with environmental protection, such as the Wild Bucovina Association, which in addition to researching and protecting ecosystems organizes photo tours and promotes sustainable tourism, works in partnership with rangers in parks national, protected areas.

Last but not least is the principle that ecotourism must have a minimal negative impact. Why at least? Because any human activity has a negative impact: when I go hiking, I step on the grass and the food chain is affected, when I drive I pollute the air, which leads to changes in ecosystems over time and I could continue, I could find an impact negative on the environment in any human activity, but we are currently looking to minimize the damage we do to the environment. From the point of view of waste in Bucovina is clean and it is carefully collected and transported away from the tourist area, and on the roads you do not see garbage, and houses, guesthouses and hotels are decorated with flowers. The education, traditions, added value and hospitality of the people of Bucovina is visible wherever you move in this area.

\section{Conclusions}

In conclusion we can say that we have demonstrated that Bucovina can be an ecotourism destination in Romania, because:

- it has a rich natural and anthropic patrimony, the natural one being made up of national parks and protected areas, and the anthropic patrimony is made up of monasteries, some under UNESCO protection, of medieval fortresses, of memorial houses, monuments, etc.

- the education in the school and through events of the locals for the protection of the environment and for responsible tourism is developed

- educate tourists for a sustainable tourism through the information received from guides and through direct contact with culture and traditions

- modern and environmentally friendly accommodation and restoration spaces are provided

- unique experiences are created for both hosts and tourists 
- economic surplus value is realized from the sale of traditionally obtained goods, and a part of these is returned for the conservation of the patrimony

- a communion is formed between the local authorities, private entrepreneurs and NGOs for the realization of ecotourism, for sustainable development of the area

- the locals have a job and this makes them responsible and increases their respect and confidence in their own strengths, they are the ones who create their own businesses or work in protected areas

In conclusion, there are all the elements in Bucovina for the area to become a region where ecotourism is paramount, but it is not yet an ecotourism destination because it does not have a destination management developed and a marketing plan to be developed in time. long, in which to present all these beauties from nature, to people.

\section{Acknowledgement}

This work is supported by project POCU 125040, entitled "Development of the tertiary university education to support the economic growth PROGRESSIO", co-financed by the European Social Fund under the Human Capital Operational Program 2014-2020

\section{References}

[1] AER [Internet]. Despre ecoturism. Available from: https://www.asociatiaaer.ro/despre-ecoturism/

[2] Cantemir D. Descrierea Moldovei [Internet]. Simplesite.com. [cited 2020 september 8]. Available from: https://.bibliotecapemobil.ro/content/scoala/pdf/Descrierea Moldovei Dimitrie Cantemir.pdf

[3] Institutul National de Cercetare dezvoltare in Turism. Strategia națională de dezvoltare a ecoturismului în România - context, viziune și obiective - 20162020 [Internet]. Bucuresi: Institutul National de Cercetare dezvoltare in Turism; 2015 [cited 2020 Oct 13]. Available from: https://patrimoniu.gov.ro/images/turismcultural/Romania/Strategieecoturism.pdf

[4] Juravle AI, Sasu C, Terec-Vlad L. The destination image of bucovina among romanian tourists. Cross - Cultural Management Journal [Internet]. 2016 Nov 15[cited 2020 Oct 13];18(2):139-149 Available from: https://cmj.seaopenresearch.eu/volume-xviiï 
[5] Matei D, Chirita V. The ecotourism - element of the sustainable development of the local rural communities from Bukowina (ROMANIA). 11th

International Multidisciplinary Scientific GeoConference [Internet]. 2011 Jun [cited 2020 Oct 13]; 3:1183-1190. Available from: https://doi.org/10.5593/sgem2011/s22.134

[6] Matei D. Actual environmental features generated by the tourism in the rural space in Bucovina - Romania. 11th International Multidisciplinary Scientific GeoConference [Internet]. 2011 Jun [cited 2020 Oct 13];3:951-956. Available from: https://doi.org/10.5593/SGEM2011/S22.103

[7] Parcul Vanatori - Neamt [Internet]. [cited 2020 Sept 8]. Available from: http://vanatoripark.ro/category/biodiversitate/

[8] Rațiu M P, Stăncioiu A, Vlădoi A, Teodorescu N. Considerations regarding the design of specific tourism products for the tourism destination Romania.

Annals of the University of Petroșani. Economics [Internet]. 2011 [cited 2020 Oct 13];11(3):255-262. Available from:

https://www.upet.ro/annals/economics/pdf/annals-2011-part3.pdf

[9] Romanian Government. Strategia Nationala a Ecoturismului 2019-2029 [Internet]. Monitorul Oficial. 2019 May 30 [cited 2020 Sept 8]. Report No.:358. Available from: http://legislatie.just.ro/Public/DetaliiDocument/219401

[10] The International Ecotourism Society [Internet]. What Is Ecotourism?. Available from: https://ecotourism.org/what-is-ecotourism/

[11] Tudorache D M, Tudorache P, Aştefănoaiei M. UNESCO world heritage sites in Bucovina - an opportunity for the sustainable development of tourism. Knowledge Horizons. Economics [Internet]. 2019 [cited 2020 Oct 13];11(2):91-98. Available from: http://www.orizonturi.ucdc.ro/arhiva/KHE $\% 20 \mathrm{nr} . \% 202 \% 20$ \%202019/12.\%20UNESCO $\% 20$ WORLD $\% 20$ HERITAGE $\% 20$ SITES $\% 20 \mathrm{I}$ N\%20\%20BUCOVINA.pdf 